\title{
Pembentukan kompetensi ekologis dengan model pembelajaran kontekstual dan berbasis masalah dalam PPKn di SMP
}

\author{
Shinta Pertiwi dan Samsuri \\ Universitas Negeri Yogyakarta \\ shinta.pertiwi03@gmail.com
}

\begin{abstract}
This research based article was aimed at explaining the effect of Contextual Teaching and Learning and Problem Based Learning on the establishment of Ecological Competence in Civic Education in Junior High School. It was a quasi-experiment research with pretest-posttest control group design. The population was student grade VII of SMP Negeri 2 Surakarta. The sample was chosen randomly, consist of one classroom as experimental group and another classroom as control group. Instrument for collecting data were test, questionnaire, and observation. It can be concluded that the establishment of ecological competence among junior high school students though through contextual teaching and learning are more effective than those who were though by problem based learning and conventional one. It was indicated by the result of one way anova $F_{\text {count }}>F_{\text {table }}(24.031>3.11)$ and $\left.P=0.000<0.05\right)$.
\end{abstract}

Keywords: ecological competence, contextual teaching and learning, problem based learning

\section{Pendahuluan}

Permasalahan global di abad 21 telah mengubah dunia begitu cepat. Tidak hanya dialami negara tertentu, melainkan sudah menjadi masalah dunia. Cogan (1998, p. 7) mengidentifikasi ada tiga permasalahan global utama yang dihadapi negara-negara di seluruh dunia yaitu, berkembangnya ekonomi global, semakin pesatnya kemajuan teknologi dan komunikasi, meningkatnya populasi penduduk dunia yang diikuti dengan munculnya permasalahan lingkungan. Keterkaitan PPKn yang penting dalam pendidikan ekologi (lingkungan hidup), secara jelas terdapat komponen tentang melek lingkungan yang diadaptasi dari Simmon (1995) (McBride, Brewer, Berkowitz, \& Borrie, 2013, p. 7) yaitu: (1) Terkait dengan masalah lingkungan (moralitas);

Berkomunikasi dan menerapkan konsep ekologis; (3) Bagaimana kesadaran manusia dalam mempengaruhi lingkungan;
Pengetahuan tentang isu-isu lingkungan; (5) Kemampuan untuk menciptakan, mengevaluasi, dan mengimplementasikan rencana aksi/kegiatan; (6) Mendorong praktik dan mendukung kebijakan ramah lingkungan; (7) Kemampuan untuk memajukan suatu perubahan.

Realita dan persoalan yang terjadi bahwa berbagai isu-isu global lingkungan perlu dilakukan pembelajaran dengan pendekatan pedagogi kritis dalam pembelajaran PPKn. Berbicara tentang PPKn di persekolahan penanaman nilai-nilai lingkungan hidup sudah diintegrasikan pada mata pelajaran PPKn di dalam formal, akan tetapi guru dalam proses pembelajaran Pendidikan Kewarganegaraan hanya sebatas memberikan materi saja belum sampai menjelaskan mengenai bagaimana praktik menjadi warga negara ekologis yang memiliki pengalaman nilai-nilai dalam melestarikan lingkungan hidup baik di kehidupan masyarakat nantinya 
sehingga saat ini masih banyak peserta didik yang kurang peduli terhadap lingkungan sekitar sekolah.

Kewarganegaraan ekologis menjadi satu gagasan yang menarik dewasa ini. Kerusakan dan perlindungan terhadap lingkungan menjadi isu-isu global. Upaya pelestarian lingkungan tersebut selayaknya menjadi perhatian semua elemen pendidikan. (Aquilina, 2001, p. 10) menyatakan bahwa kebijakan pendidikan lingkungan bertujuan untuk menumbuhkan pemahaman peserta didik tentang lingkungan sebagai suatu sistem yang terintegrasi. Pelestarian lingkungan tidak hanya menjadi tanggung jawab guru mata pelajaran IPA atau Sains, tetapi oleh semua guru mata pelajaran, termasuk Pendidikan Kewarganegaraan dalam meningkatkan pemahaman peserta didik dalam kompetensi ekologis.

Pendidikan Pancasila dan Kewarganegaraan atau sering dikenal dengan istilah PPKn merupakan sarana pendidikan yang memiliki peran untuk mempersiapkan generasi muda Indonesia yang cerdas, berkarakter dengan menjunjung nilai-nilai Pancasila. PPKn dan PKn pada dasarnya adalah sama, PPKn adalah sebutan untuk kurikulum 2013, sedangkan PKn adalah sebutan yang lebih umum digunakan dan juga dipakai pada kurikulum KTSP. Sebagai program pendidikan di sekolah, PPKn memiliki tanggung jawab untuk memfokuskan pada penguatan nilai dan moral sebagai perwujudan pendidikan karakter. Sebagai mata pelajaran, PPKn tidak hanya membentuk warganegara yang cerdas saja melainkan menjadi warganegara yang baik.

PPKn sebagai pendidikan nilai memiliki esensi dan makna sebagai pendidikan moral. Wahab \& Sapriya (2011, p. 55) menyatakan bahwa PPKn di Indonesia bertujuan untuk menghasilkan warga yang demokratis yaitu warga negara yang cerdas dan memanfaatkan kecerdasannya sebagai warga negara untuk kemajuan diri dan lingkungannya. Mendidik warga negara yang demokratis melalui mata pelajaran PPKn dapat berhasil dengan baik karena bahan-bahan, metode mengajar yang digunakannya adalah bahan metode mengajar yang demokratis. Selain itu, tujuan PPKn menjadikan warga negara yang efektif yaitu warga negara yang bersifat cakap dan memiliki kepedulian (Murdiono, 2012, p. 47).

Melalui pendidikan lingkungan yang terintegrasi dalam mata pelajaran diharapkan dapat mencapai tingkat kompetensi dan kewarganegaraan di semua peserta didik sehingga dapat berkontribusi pada pencapaian masyarakat yang berkelanjutan, tetapi dampak dari hasil pendidikan lingkungan hidup yang telah dilaksanakan di lembagalembaga pendidikan belum banyak terlihat, baik pada masyarakat maupun lingkungan. Sebaliknya berbagai permasalahan lingkungan hidup yang berakar dari perilaku manusia masih sering kita temukan dalam kehidupan sehari-hari. Metode pelaksanaan pendidikan lingkungan hidup tidak aplikatif, kurang mendukung penyelesaian permasalahan lingkungan hidup yang dihadapi di daerah masing-masing. Hal ini secara tidak langsung merupakan indikasi bahwa secara umum konsepsi pendidikan lingkungan hidup di sekolah lebih banyak pada tatanan ide dan instrumental lingkungan hidup di sekolah. Oleh karena itu, kajian terhadap pelaksanaan pembelajaran pendidikan lingkungan hidup selama ini sangat perlu dilakukan, kita perlu mengkaji strategi pembelajaran dan penyediaan pengalaman belajar pada peserta didik dengan menerapkan model pembelajaran yang efektif (Gunawati, 2012, p. 140). 
Di Indonesia krisis moral terutama terkait dengan kurangnya pemahaman kesadaran siswa akan nilai-nilai ekologis di sekolah belum mencapai tujuan yang diharapkan. Berdasarkan hasil pra survey yang dilakukan peneliti di SMP Negeri 2 Surakarta diperoleh informasi bahwa kepedulian peserta didik di sekolah kurang dalam merawat, melestarikan lingkungan sekitar sekolah. Aktivitas para warga sekolah dalam kehidupan sehari-hari masih belum mencerminkan kepedulian lingkungan, misalnya penggunaan teknologi canggih yang tidak ramah lingkungan, sebagian guru yang memasukan dan mengaitkan kajian tentang lingkungan alam dalam RPP, tidak hemat dalam penggunaan energi dalam kegiatan pengajaran, misalnya penggunaan proyektor dan pengeras suara, penggunaan air keran di kamar mandi sekolah yang lupa dimatikan, konsentrasi pembuangan sampah paling tinggi berada di area kegiatan belajar mengajar (kelas, laboratorium, perpustakaan, dan lapangan olahraga) yaitu sebanyak $72 \%$. Konsentrasi pembuangan sampah di area kantin sebesar 22\%. Dapat diketahui bahwa 94\% sampah ditemukan di dua area yaitu di kegiatan belajar mengajar dan kantin sekolah. Aktivitas-aktivitas tersebut mengakibatkan kondisi lingkungan hidup yang semakin memprihatinkan di SMP Negeri 2 Surakarta.

Permasalahan yang ditemukan dalam pembelajaran PPKn yaitu proses pembelajaran dan model yang digunakan kurang meningkatkan keaktifan peserta didik dalam belajar, model pembelajaran dengan mengaitkan ke dunia nyata dalam menemukan masalah yang kompleks belum diimplementasikan guru. Pembelajaran PPKn hanya berfokus pada aspek kognitif. Guru belum maksimal dalam mengembangkan nilai-nilai ekologis karena dalam mengembangkan sebuah nilai ekologis dinilai tidak semudah membalikkan telapak tangan. Untuk itu perlu adanya suatu pendekatan pembelajaran PPKn yang dikembangkan dalam upaya membentuk kompetensi ekologis peserta didik.

Salah satu pendekatan pembelajaran yang sesuai dengan Kurikulum 2006 (KTSP) dan Kurikulum 2013 menuntut peserta didik untuk berpartisipasi aktif baik secara individu maupun kelompok dalam pembelajaran, mengaitkan isu-isu dalam dunia nyata, dan peserta didik dapat menemukan solusi permasalahan isu lingkungan hidup adalah dengan menggunakan pendekatan pembelajaran melalui model pembelajaran kontekstual (Contextual Teaching and Learning) dan pembelajaran berbasis masalah. Guru mata pelajaran PPKn di SMP Negeri 2 Surakarta sudah menggunakan model pembelajaran tersebut, tetapi dalam rangka membentuk kompetensi ekologis peserta didik belum dikaitkan dengan materi pembelajaran. (Johnson, 2011, p. 59) menyatakan bahwa model kontekstual menolong siswa dalam mengidentifikasi proyek, masalah, yang menempatkan pelajaran di dalam situasi dunia nyata.

Upaya meningkatkan kesadaran pelestarian lingkungan hidup melalui pembelajaran PKLH berbasis CTL dapat dilihat dari hasil penelitian yang dilakukan Puspandari (2008, pp. 29-30) ditemukan adanya pengalaman belajar, kreativitas, dan pemahaman siswa dalam konteks yang bermakna. Model pembelajaran lain yang sesuai diterapkan dalam muatan ekologis adalah model pembelajaran berbasis masalah disebut juga dengan Problem Based Learning (PBL).

Hosnan (2014, p. 229) menyatakan bahwa tujuan utama pembelajaran berbasis 
masalah bukanlah penyampaian sejumlah besar pengetahuan kepada peserta didik, melainkan pada pengembangan kemampuan berfikir kritis dan kemampuan memecahkan masalah dan sekaligus mengembangkan kemampuan peserta didik untuk secara aktif membangun pengetahuannya. Husna, Nurmaliah, \& Abdullah (2013, p. 97) menyatakan bahwa model pembelajaran berbasis masalah dapat meningkatkan sikap peduli lingkungan siswa dengan persentase gain score ternormalisasi sebesar 61,42 untuk kelas eksperimen dalam kategori sedang dan 40,13 untuk kelas kontrol dalam kategori sedang. Berdasarkan pendapat tersebut dapat diketahui bahwa penerapan model pembelajaran berbasis masalah dapat meningkatkan kemampuan berfikir kritis, menumbuhkan inisiatif peserta didik.

Atas dasar pemikiran inilah dalam menumbuhkan kompetensi ekologis peserta didik dengan mengintegrasikan muatan ekologis pada mata pelajaran PPKn perlu dilakukan dengan penerapan model pembelajaran yang inovatif dengan menerapkan model pembelajaran kontekstual dan pembelajaran berbasis masalah. Berdasarkan karakteristik masalah di atas, maka peneliti tertarik untuk melakukan penelitian mengenai "Pembentukan Kompetensi Ekologis Dengan Model Pembelajaran Kontekstual dan Berbasis Masalah Dalam PPKn Di SMP Kelas VII”.

\section{Metode}

Penelitian ini merupakan penelitian eksperimen semu (quasi experiment). Desain penelitian menggunakan pretest-posttest control group design. Kelas yang digunakan dalam penelitian dibagi menjadi kelas eksperimen dan kelas kontrol. Pengelompokan kelas dalam 3 kelompok, yaitu 2 kelompok eksperimen dan 1 kelompok kontrol. Teknik dan instrumen pengumpulan data digunakan untuk mengukur kompetensi ekologis. Kompetensi ekologis yang meliputi dimensi pengetahuan, sikap, dan keterampilan. Tes yang digunakan adalah untuk mengumpulkan data yang berkaitan dengan hasil belajar aspek pengetahuan. Aspek pengetahuan dalam hal ini adalah untuk memenuhi kompetensi pengetahuan ekologis peserta didik. Angket yang digunakan dalam penelitian ini adalah angket yang bertujuan untuk mengukur sikap ekologis peserta didik. Angket dilaksanakan dua kali yakni pada awal sebelum perlakuan (pretest) dan setelah mendapat perlakuan (posttest). Selanjutnya teknik pengumpulan data observasi menggunakan instrumen non tes yaitu menggunakan pedoman observasi untuk mengamati pengaruh keaktifan di kelas dalam membentuk kompetensi ekologis pada aspek keterampilan yang harus dimiliki peserta didik guna memberikan kesempatan bagi peserta didik untuk berkembang menjadi warga lingkungan yang efektif dan berkomitmen.

\section{Hasil dan Pembahasan}

Penelitian ini terdapat 3 (tiga) kelompok data yang perlu dideskripsikan sesuai rancangan penelitian eksperimen yang menggunakan dua kelas eksperimen, yaitu model kontekstual dan berbasis masalah, satu kelas kontrol yaitu, model konvensional yang digunakan guru kelas yaitu model yang digunakan guru dalam pembelajaran seharihari dengan menggunakan model yang bersifat umum.

Sebagai hasil proses belajar dalam mata pelajaran PPKn kurikulum 2013 kompetensi ekologis atau hasil penilaian dalam penelitian ini dapat dijelaskan oleh 3 aspek penilaian yang berupa aspek pengetahuan, sikap, dan keterampilan. 
Tabel 1 Deskripsi Data Pretest Kompetensi Ekologis Aspek Pengetahuan

\begin{tabular}{lccc}
\hline $\begin{array}{c}\text { Hasil } \\
\text { Deskriptif }\end{array}$ & $\begin{array}{c}\text { Model } \\
\text { CTL }\end{array}$ & $\begin{array}{c}\text { Model } \\
\text { PBL }\end{array}$ & $\begin{array}{c}\text { Model } \\
\text { Konvensional } \\
\text { (Kelas } \\
\text { Kontrol) }\end{array}$ \\
\hline Mean & 2,83 & 2,86 & 2,69 \\
Median & 2,88 & 2,88 & 2,72 \\
Mode & 2,88 & 2,88 & 2,88 \\
Std. deviasi & 0,294 & 0,238 & 0,250 \\
Max & 3,36 & 3,36 & 3,04 \\
Min & 2,08 & 2,40 & 2,08 \\
\hline
\end{tabular}

Sumber: Data hasil penelitian, 2017.

Data di atas menunjukkan nilai rerata pretest pembentukan kompetensi ekologis pada aspek pengetahuan pada kelompok eksperimen 1 yaitu kelas mengikuti pembelajaran model kontekstual sebesar 2,83; median 2,88; mode 2,88; standar deviasi 0,294; skor tertinggi 3,36 dan skor terendah 2,08. Selanjutnya nilai rerata pretest aspek pengetahuan pada kelompok eksperimen 2 yaitu kelas mengikuti pembelajaran model berbasis masalah (PBL) sebesar 2,86; median 2,88; mode 2,88; standar deviasi 0,238; skor tertinggi 3,36 dan skor terendah 2,40. Kemudian Nilai rerata pretest pembentukan kompetensi ekologis aspek pengetahuan pada kelompok kelas kontrol dengan model konvensional sebesar 2,69; median 2,72; mode 2,88; standar deviasi 0,250 ; skor tertinggi 3,04 dan skor terendah 2,08.

Tabel 2 Deskripsi Data Posttest Kompetensi Ekologis Aspek Pengetahuan

\begin{tabular}{lccc}
\hline $\begin{array}{c}\text { Hasil } \\
\text { Deskriptif }\end{array}$ & $\begin{array}{c}\text { Model } \\
\text { CTL }\end{array}$ & $\begin{array}{c}\text { Model } \\
\text { PBL }\end{array}$ & $\begin{array}{c}\text { Model } \\
\text { Konvensional } \\
\text { (Kelas } \\
\text { Kontrol) }\end{array}$ \\
\hline Mean & 3,38 & 3,22 & 3,21 \\
Median & 3,36 & 3,20 & 3,20 \\
Mode & 3,36 & 3,20 & 3,04 \\
Std. deviasi & 0,200 & 0,178 & 0,170 \\
Max & 3,84 & 3,68 & 3,52 \\
Min & 3,04 & 3,04 & 3,04 \\
\hline
\end{tabular}

Sumber: Data hasil penelitian, 2017.

Data di atas menunjukkan nilai rerata posttest pembentukan kompetensi ekologis aspek pengetahuan pada kelompok eksperimen 1 yaitu kelas menggunakan model pembelajaran kontekstual sebesar 3,38; median 3,36; mode 3,36; standar deviasi 0,200; skor tertinggi 3,84 dan skor terendah 3,04. Selanjutnya nilai rerata posttest pembentukan kompetensi ekologis aspek pengetahuan pada kelompok eksperimen 2 yaitu kelas menggunakan model pembelajaran berbasis masalah (PBL) sebesar 3,22; median 3,20; mode 3,20; standar deviasi 0,178 ; skor tertinggi 3,68 dan skor terendah 3,04. Kemudian Nilai rerata posttest pembentukan kompetensi ekologis aspek pengetahuan pada kelompok kelas kontrol dengan model konvensional sebesar 3,21; median 3,20; mode 3,20; standar deviasi 0,170 ; skor tertinggi 3,52 dan skor terendah 3,04 .

Data sikap pembentukan kompetensi ekologis diperoleh melalui angket yang diberikan kepada peserta didik melalui angket sikap ekologis dengan 46 butir pernyataan yang berupa pernyataan positif dan negatif. Hasil penilaian dalam aspek pembentukan sikap ekologis pada 2 kelas eksperimen dan 1 kelas kontrol dapat disajikan pada Tabel 3.

Tabel 3 Deskripsi Data Pretest Kompetensi Ekologis Aspek Sikap

\begin{tabular}{|c|c|c|c|}
\hline $\begin{array}{c}\text { Hasil } \\
\text { Deskriptif }\end{array}$ & $\begin{array}{c}\text { Model } \\
\text { CTL }\end{array}$ & $\begin{array}{c}\text { Model } \\
\text { PBL }\end{array}$ & $\begin{array}{c}\text { Model } \\
\text { Konvensional } \\
\text { (Kelas } \\
\text { Kontrol) } \\
\end{array}$ \\
\hline Mean & 2,33 & 2,46 & 2,03 \\
\hline Median & 2,42 & 2,80 & 1,73 \\
\hline Mode & 1,74 & 1,83 & 1,74 \\
\hline $\begin{array}{l}\text { Std. } \\
\text { deviasi }\end{array}$ & 0,598 & 0,659 & 0,613 \\
\hline Max & 3,15 & 3,15 & 3,15 \\
\hline Min & 1,52 & 1,52 & 1,52 \\
\hline \multicolumn{4}{|c|}{$\begin{array}{l}\text { Sumber: Data hasil penelitian, } 2017 \text {. } \\
\text { ata di atas menunjukkan nilai rerata } \\
t \text { pembentukan kompetensi ekologis } \\
\text { spek sikap pada kelompok eksperimen } \\
\text { tu kelas menggunakan pembelajaran } \\
\text { kontekstual sebesar } 2,33 \text {; median } 2,42 \text {; }\end{array}$} \\
\hline
\end{tabular}


mode 1,74 ; standar deviasi 0,598 ; skor tertinggi 3,15 dan skor terendah 1,52. Selanjutnya nilai rerata pretest aspek sikap pada kelompok eksperimen 2 yaitu kelas menggunakan pembelajaran model berbasis masalah (PBL) sebesar 2,46; median 2,80; mode 1,83 ; standar deviasi 0,659 ; skor tertinggi 3,15 dan skor terendah 1,52. Kemudian Nilai rerata pretest pembentukan kompetensi ekologis aspek sikap pada kelompok kelas kontrol dengan model konvensional sebesar 2,03; median 1,73; mode 1,74 ; standar deviasi 0,613 ; skor tertinggi 3,15 dan skor terendah 1,52.

Tabel 4 Deskripsi Data Posttest Kompetensi Ekologis Aspek Sikap

\begin{tabular}{lccc}
\hline $\begin{array}{c}\text { Hasil } \\
\text { Deskriptif }\end{array}$ & $\begin{array}{c}\text { Model } \\
\text { CTL }\end{array}$ & $\begin{array}{c}\text { Model } \\
\text { PBL }\end{array}$ & $\begin{array}{c}\text { Model } \\
\text { Konvensional } \\
\text { (Kelas } \\
\text { Kontrol) }\end{array}$ \\
\hline Mean & 3,17 & 3,06 & 2,95 \\
Median & 3,23 & 3,05 & 2,91 \\
Mode & 2,80 & 2,72 & 2,91 \\
Std. & 0,231 & 0,237 & 0,171 \\
deviasi & & & \\
Max & 3,50 & 3,61 & 3,37 \\
Min & 2,72 & 2,72 & 2,72 \\
\hline
\end{tabular}

Sumber: Data hasil penelitian, 2017.

Data di atas menunjukkan nilai rerata posttest pembentukan kompetensi ekologis aspek sikap pada kelompok eksperimen 1 yaitu kelas menggunakan model pembelajaran kontekstual sebesar 3,17; median 3,23; mode 2,80; standar deviasi 0,231; skor tertinggi 3,50 dan skor terendah 2,72. Selanjutnya nilai rerata posttest pembentukan kompetensi ekologis aspek sikap pada kelompok eksperimen 2 yaitu kelas menggunakan model pembelajaran berbasis masalah (PBL) sebesar 3,06; median 3,05 ; mode 2,72; standar deviasi 0,237 ; skor tertinggi 3,61 dan skor terendah 2,72. Kemudian Nilai rerata posttest pembentukan kompetensi ekologis aspek sikap pada kelompok kelas kontrol dengan model konvensional sebesar 2,95; median 2,91; mode 2,91; standar deviasi 0,171; skor tertinggi 3,37 dan skor terendah 2,72.

Hasil belajar pada aspek keterampilan ekologis diperoleh melalui observasi presentasi hasil kerja peserta didik pada kegiatan mengomunikasikan, sebagai outcome dari pemahaman ranah pengetahuan dan wujud dari ranah sikap. Hasil penilaian aspek keterampilan ekologis ditunjukkan pada Tabel 5.

Tabel 5 Deskripsi Data Posttest Kompetensi Ekologis Aspek Keterampilan

\begin{tabular}{lccc}
\hline $\begin{array}{c}\text { Hasil } \\
\text { Deskriptif }\end{array}$ & $\begin{array}{c}\text { Model } \\
\text { CTL }\end{array}$ & $\begin{array}{c}\text { Model } \\
\text { PBL }\end{array}$ & $\begin{array}{c}\text { Model } \\
\text { Konvensional } \\
\text { (Kelas } \\
\text { Kontrol) }\end{array}$ \\
\hline Mean & 3,28 & 2,85 & 1,89 \\
Median & 3,40 & 2,80 & 1,80 \\
Mode & 3,40 & 2,80 & 1,60 \\
Std. & 0,299 & 0,280 & 0,342 \\
deviasi & & & \\
Max & 3,80 & 3,60 & 2,80 \\
Min & 2,40 & 2,40 & 1,60 \\
\hline
\end{tabular}

Sumber: Data hasil penelitian, 2017.

Data di atas menunjukkan nilai rerata posttest pembentukan kompetensi ekologis aspek keterampilan pada kelompok eksperimen 1 yaitu kelas menggunakan model pembelajaran kontekstual sebesar 3,28; median 3,40; mode 3,40; standar deviasi 0,299; skor tertinggi 3,80 dan skor terendah 2,40. Selanjutnya nilai rerata posttest pembentukan kompetensi ekologis aspek keterampilan pada kelompok eksperimen 2 yaitu kelas menggunakan model pembelajaran berbasis masalah (PBL) sebesar 2,85; median 2,80; mode 2,80; standar deviasi 0,280; skor tertinggi 3,60 dan skor terendah 2,40. Kemudian Nilai rerata posttest pembentukan kompetensi ekologis aspek keterampilan pada kelompok kelas kontrol dengan model konvensional sebesar 1,89; median 1,80; mode 1,60; standar deviasi 0,342 ; skor tertinggi 2,80 dan skor terendah 1,60 . 
Hasil hipotesis pertama dan kedua analisis yang digunakan menggunakan uji t. Analisis yang menggunakan uji-t akan dinyatakan signifikan jika taraf signifikansinya kurang dari 0,05 atau nilai $t_{\text {hitung }}>\mathrm{t}_{\text {tabel. }}$. Jadi hipotesis dalam penelitian ini dinyatakan signifikan jika pada analisis dinyatakan ada perbedaan dan dinyatakan tidak signifikan jika hasil posttest dari kedua kelas tersebut tidak ada perbedaan. Dapat dilihat pada Tabel 6 dan 7 .

Tabel 6 Hasil Uji t Pembentukan Kompetensi Ekologis Kelas Eksperimen 1 dengan Kelas Kontrol

\begin{tabular}{|c|c|c|c|}
\hline Kelas & Mean & t hitung & Nilai $p$ \\
\hline Posttest & & \multirow{6}{*}{7,440} & \multirow{6}{*}{0,000} \\
\hline $\begin{array}{l}\text { Eksperimen } 1 \\
\text { (Model }\end{array}$ & 82,28 & & \\
\hline kontekstual) & & & \\
\hline Posttest & \multirow{3}{*}{75,27} & & \\
\hline Kontrol (Model & & & \\
\hline Konvensional) & & & \\
\hline \multirow{4}{*}{\multicolumn{4}{|c|}{$\begin{array}{c}\text { Sumber: Data hasil penelitian, } 2017 . \\
\text { Tabel } 7 \text { Hasil Uji t Pembentukan } \\
\text { Kompetensi Ekologis Kelas Eksperimen } 2 \\
\text { dengan Kelas Kontrol }\end{array}$}} \\
\hline & & & \\
\hline & & & \\
\hline & & & \\
\hline Kelas & Mean & t hitung & Nilai p \\
\hline \multicolumn{2}{|l|}{ Posttest } & \multirow{5}{*}{3,253} & \multirow{5}{*}{0,002} \\
\hline $\begin{array}{l}\text { Eksperimen } 2 \\
\text { (Model }\end{array}$ & 78,57 & & \\
\hline kontekstual) & & & \\
\hline Posttest & & & \\
\hline $\begin{array}{l}\text { Kontrol (Model } \\
\text { Konvensional) }\end{array}$ & 75,27 & & \\
\hline
\end{tabular}

Sumber: Data hasil penelitian, 2017

Kemudian hasil uji hipotesis ketiga dalam penelitian ini adalah terdapat perbedaan pengaruh model kontekstual dan pembelajaran berbasis masalah terhadap pembentukan kompetensi ekologis pada mata pelajaran PPKn menggunakan analisis varian satu jalur (One Way Anova). Kriteria Pengujiannya adalah apabila $\mathrm{F}$ hitung lebih besar dari $\mathrm{F}$ tabel dan taraf signifikansinya < 0,05 maka terdapat perbedaan. Sebaliknya apabila $\mathrm{F}$ hitung lebih kecil dari $\mathrm{F}$ tabel dan taraf signifikansi > 0,05 maka tidak ada perbedaan menggunakan bantuan program SPSS versi 16.0 for Windows sebagai aplikasi untuk memudahkan berbagai penelitian.

Tabel 8 Rangkuman Hasil One Way Anova Pembentukan Komp. Ekologis Kelas Eksperimen 1, 2 dan Kelas Kontrol

\begin{tabular}{llll}
\hline \multicolumn{1}{c}{ Data } & Mean & F hitung & Nilai P \\
\hline $\begin{array}{l}\text { Post Eksp. } \\
\text { 1Model }\end{array}$ & 82,28 & & \\
Kontekstal & & &
\end{tabular}

Kontekstual

Post Eksp. 78,57

2Model PBL $\quad 24,031 \quad 0,000$

Post Kelas $\quad 75,27$

Kontrol

Model

Konvensional

Sumber: Data hasil penelitian, 2017.

Tabel 9 Hasil Gain Score Pembentukan Kompetensi Ekologis

\begin{tabular}{lcc}
\hline \multicolumn{1}{c}{ Kelas } & Gain Score & Kategori \\
\hline $\begin{array}{l}\text { Eksperimen 1 } \\
\text { (model }\end{array}$ & 0,49 & Sedang \\
$\begin{array}{l}\text { kontekstual) } \\
\begin{array}{l}\text { Eksperimen 1 } \\
\text { (model PBL) }\end{array}\end{array}$ & 0,28 & Rendah \\
$\begin{array}{l}\text { Kontrol } \\
\text { (model } \\
\text { konvensional) }\end{array}$ & 0,20 & Rendah \\
\hline
\end{tabular}
Sumber: Data hasil penelitian, 2017.

Berdasarkan hasil ringkasan analisis varian (One Way Anova) dan tabel gain score masing-masing kelas eksperimen di atas, dapat dijelaskan hasil uji hipotesis sebagai berikut:

Hipotesis Pertama

Pada tabel 6 dapat diketahui bahwa perhitungan tentang penerapan model pembelajaran kontekstual dalam pembelajaran PPKn berpengaruh terhadap pembentukan kompetensi ekologis peserta didik dalam pembelajaran PPKn. Hal ini ditunjukkan dari nilai $t_{\text {hitung }}>\mathrm{t}_{\text {tabel }}(7,440>$ $2,00324)$ atau nilai p lebih kecil dari $0,05(\mathrm{p}=$ $0,000<0,05)$.

Berdasarkan tabel 9 dapat dilihat bahwa perolehan gain score pada kelas eksperimen 
yang menggunakan model kontekstual sebesar 0,49 dalam kategori efektivitas sedang. Sementara perolehan gain score pada kelas kontrol yang menggunakan model konvensional sebesar 0,20 dalam kategori efektivitas rendah. Berdasarkan hasil tersebut, maka hipotesis dalam penelitian ini diterima yakni penerapan model kontekstual dalam pembelajaran PPKn berpengaruh terhadap pembentukan kompetensi ekologis peserta didik dalam pembelajaran PPKn di SMP Negeri 2 Surakarta.

Hasil penelitian ini menguatkan penelitian terdahulu yang dilakukan oleh Sumarmi (2008) menyimpulkan bahwa melalui kontekstual, sekolah hijau dapat menciptakan pelajaran yang lebih bermakna, membuat lingkungan pendidikan menjadi nyata. Penelitian tersebut menjadi dasar pada penelitian yang dilakukan di SMP Negeri 2 Surakarta ini bahwa dalam meningkatkan pembelajaran PPKn terhadap pembentukan kompetensi ekologis di sekolah yang berwawasan lingkungan diarahkan pada pengembangan pengetahuan, kesadaran, sikap positif, dan perilaku bertanggung jawab terhadap lingkungan, pendekatan pembelajaran yang menyenangkan yang sesuai dengan peningkatan kompetensi ekologis untuk sekolah hijau menggunakan model pembelajaran kontekstual.

Belajar dengan model pembelajaran kontekstual baru dapat terjadi apabila peserta didik telah dapat mengaplikasikan dan mengalami apa yang sedang diajarkan/ dipelajari. Hal ini sejalan dengan penjelasan McCombs (Jeynes, 2010, p. 264) bahwa apa dan berapa banyak yang dapat dipelajari seseorang itu tergantung dari motivasi dan faktor lingkungannya serta keberhasilan sebuah pembelajaran yaitu dapat menghubungkan informasi dengan informasi yang ada. Berdasarkan uraian di atas dapat disimpulkan bahwa penerapan model pembelajaran kontekstual dalam pembelajaran PPKn berpengaruh terhadap kompetensi ekologis peserta didik dalam pembelajaran PPKn di SMP Negeri 2 Surakarta.

Hipotesis Kedua

Pada tabel 7 dapat diketahui bahwa perhitungan tentang penerapan model pembelajaran berbasis masalah dalam pembelajaran PPKn berpengaruh terhadap pembentukan kompetensi ekologis peserta didik dalam pembelajaran PPKn. Hal ini ditunjukkan dari nilai $t_{\text {hitung }}>t_{\text {tabel }}(3,253>$ $2,00488)$ atau nilai $\mathrm{p}$ lebih kecil dari $0,05(\mathrm{p}=$ $0,002<0,05)$.

Berdasarkan tabel 9 dapat dilihat bahwa Perolehan gain score pada kelas eksperimen yang menggunakan model pembelajaran berbasis masalah sebesar 0,28 dalam kategori efektivitas rendah. Sementara perolehan gain score pada kelas kontrol yang menggunakan model konvensional sebesar 0,20 dalam kategori efektivitas rendah. Hal ini diperkuat dengan pendapat Uden \& Beaumont (2006, p. 31) bahwa kelebihan model pembelajaran berbasis masalah yakni ada bukti kuat bahwa peserta didik yang diajar dengan menggunakan PBL lebih mempertahankan pengetahuannya lebih lama dibandingkan dengan peserta didik yang diajar dengan pengajaran tradisional.

Hal ini dapat terjadi karena dalam model pembelajaran ini tidak hanya mengamati apa yang diperagakan, dan mendengarkan apa yang dikatakan guru, menulisnya di buku catatan, tetapi peserta didik yang melakukan, peserta didik menyelidiki sendiri masalah, dan menemukan sendiri pemecahan masalahnya. Model pembelajaran berbasis masalah mendorong peserta didik untuk 
mengembangkan pemikiran kritis dan kemampuan menyelesaikan masalah.

Selain itu, model pembelajaran berbasis masalah bisa dikatakan sebagai suatu strategi dalam proses pembelajaran karena model pembelajaran berbasis masalah merupakan salah satu alternatif bagi guru terutama dalam menghadapi persoalan-persoalan yang harus dipecahkan secara bersama khususnya terkait permasalahan ekologi baik lokal, nasional maupun global dalam mata pelajaran PPKn jika terkesan pembelajaran berjalan satu arah di saat pembelajaran berlangsung. Hal ini diperkuat oleh pendapat Echavarria (2010, p. 86) bahwa pembelajaran berbasis masalah adalah strategi pedagogis yang berpusat pada peserta didik dengan mengkaji masalahmasalah dalam kehidupan sehari-hari dan bekerja dalam tim atau kelompok, dengan demikian dapat melatih peserta didik untuk bertanggung jawab dalam pembelajaran mereka sendiri dan mengubah peran pendidik menjadi fasilitator.

Hal ini juga diperkuat dengan pendapat Schettino (Schettino, 2016, p. 8) bahwa melalui pembelajaran berbasis masalah di dalam kelas adalah tempat di mana merangsang kemampuan berkomunikasi, keterampilan meta kognitif, keterampilan belajar seumur hidup, dan pengetahuan konten dipraktikkan dengan berfokus pada masalah.

Selanjutnya penelitian ini sejalan dengan penelitian yang dilakukan Yuniwati \& Siasah (2016, p. 208) bahwa penerapan model Problem Based Learning dapat meningkatkan kualitas pembelajaran PPKn pada aspek proses pembelajaran dan hasil belajar yang komprehensif (kognitif, afektif, dan psikomotorik). Hasil penelitian menunjukkan aktivitas siswa memiliki potensi yang cukup baik dalam menyelesaikan masalah yang diberikan asal siswa diberi kesempatan dan fasilitas serta pendampingan yang tepat.

Dengan demikian bahwa pembelajaran berbasis masalah di SMP Negeri 2 Surakarta dalam menumbuhkan kompetensi ekologis siswa pada mata pelajaran PPKn mendorong peserta didik untuk berkolaborasi dengan teman sejawat dan orang lain, sehingga peserta didik terlibat aktif dalam penyelidikan untuk pemecahan masalah. Berdasarkan uraian di atas dapat disimpulkan bahwa penerapan model pembelajaran berbasis masalah (PBL) dalam pembelajaran PPKn berpengaruh terhadap kompetensi ekologis peserta didik di SMP Negeri 2 Surakarta.

Hipotesis Ketiga

Pada tabel 8 dapat diketahui bahwa perhitungan tentang pembentukan kompetensi ekologis antara peserta didik yang menggunakan model pembelajaran kontekstual lebih berpengaruh dibandingkan dengan pembelajaran berbasis masalah dan model pembelajaran konvensional (kelas kontrol). Hal ini dapat dilihat dari hasil uji One Way Anova yang menunjukkan bahwa nilai $F_{\text {hitung }}>F_{\text {tabel }}(24,031>3,11)$ atau nilai $p$ lebih kecil dari 0,05 ( $\mathrm{p}=0,000<0,05)$.

Berdasarkan tabel 9 perolehan gain score model pembelajaran kontekstual, pembelajaran berbasis masalah, dan model pembelajaran konvensional juga dapat dilihat pada gambar di bawah ini.

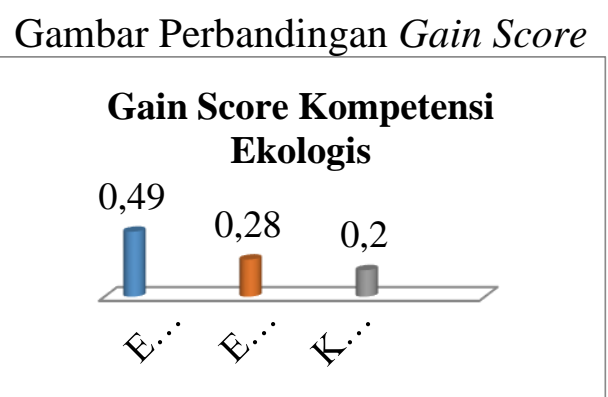

Sumber: Data hasil penelitian, 2017. Gambar di atas menunjukkan bahwa peserta didik yang menggunakan pembelajaran kontekstual memperoleh gain 
score sebesar 0,49 (kelas eksperimen 1). Kemudian peserta didik yang menggunakan model pembelajaran berbasis masalah (kelas eksperimen 2) memperoleh gain score sebesar 0,28. Sementara pada kelas kontrol yang menggunakan model pembelajaran konvensional memperoleh gain score 0,20. Hasil tersebut menunjukkan penerapan kontekstual lebih berpengaruh terhadap pembentukan kompetensi ekologis peserta didik pada mata pelajaran PPKn di SMP Negeri 2 Surakarta.

Hasil penelitian ini juga dikuatkan oleh Setyati (2013) bahwa kontekstual memiliki keefektifan lebih dibandingkan model pembelajaran lainnya. Hasil penelitian ini menunjukkan bahwa penerapan kontekstual dapat meningkatkan hasil belajar siswa. Penerapan model cooperative learning dapat meningkatkan hasil belajar siswa. kontekstual lebih efektif dalam meningkatkan hasil belajar siswa pada pelajaran Pendidikan Kewarganegaraan. Hal ini sejalan dengan Suryawati, Osman, \& Meerah (2010, p. 1718) memberikan pengertian pembelajaran kontekstual yakni suatu pendekatan pembelajaran yang membantu siswa untuk dapat menghubungkan materi yang dipelajari dengan kehidupan sehari-hari siswa serta mendorong siswa untuk dapat menggunakan pengetahuannya dalam kehidupan sehari-hari.

Terkait hal tersebut maka, dalam pendidikan lingkungan yang terintegrasi ke dalam mata pelajaran PPKn untuk pembentukan kompetensi ekologis sesuai dengan langkah-langkah kontekstual bahwa dalam pembentukan kompetensi ekologis dengan pembelajaran kontekstual peserta didik diperkenalkan dengan konsep pendidikan yang menyatu dengan alam dan belajar melalui eksplorasi/penemuan. Berdasarkan uraian di atas dapat disimpulkan bahwa kompetensi ekologis dilihat pada aspek pengetahuan, sikap, dan keterampilan peserta didik yang menggunakan model pembelajaran kontekstual lebih baik dibandingkan model pembelajaran berbasis masalah dan model pembelajaran konvensional (kelas kontrol).

\section{Simpulan}

Penerapan model pembelajaran kontekstual berpengaruh terhadap pembentukan kompetensi ekologis peserta didik pada mata pelajaran PPKn. Hal ini ditunjukkan dari nilai $t_{\text {hitung }}>t_{\text {tabel }}(7,440>$ $2,00324)$ atau nilai $\mathrm{p}$ lebih kecil dari $0,05(\mathrm{p}=$ $0,000<0,05)$.

Penerapan model pembelajaran berbasis masalah berpengaruh terhadap pembentukan kompetensi ekologis peserta didik pada mata pelajaran PPKn. Hal ini ditunjukkan dari nilai $t_{\text {hitung }}>t_{\text {tabel }}(3,253>2,00488)$ atau nilai $p$ lebih kecil dari 0,05 ( $\mathrm{p}=0,002<0,05)$.

Penerapan model pembelajaran kontekstual dan pembelajaran berbasis masalah berpengaruh terhadap pembentukan kompetensi ekologis peserta didik pada mata pelajaran PPKn. Hasil tersebut menunjukkan penerapan kontekstual lebih berpengaruh terhadap pembentukan kompetensi ekologis peserta didik pada mata pelajaran PPKn di SMP Negeri 2 Surakarta. Hal ini dapat dilihat dari hasil uji one way anova yang menunjukkan bahwa nilai $F_{\text {hitung }}>F_{\text {tabel }}$ $(24,031>3,11)$ atau nilai $p$ lebih kecil dari $0,05(\mathrm{p}=0,000<0,05)$.

Implikasi dari penelitian ini adalah sebagai salah satu upaya mengembangkan kemampuan peserta didik dalam menemukan dan memecahkan masalah terutama terkait dengan isu-isu lingkungan yang berkaitan dengan hasil belajar terhadap pembentukan kompetensi ekologis peserta didik, maka model pembelajaran alternatif yang dapat 
digunakan adalah model pembelajaran kontekstual dan pembelajaran berbasis masalah. Hal ini dikarenakan berdasarkan kedua model pembelajaran ini sama-sama efektif dalam pembentukan kompetensi ekologis peserta didik.

Selain itu, peserta didik juga akan lebih termotivasi dalam mengikuti pembelajaran PPKn. Model pembelajaran kontekstual dan pembelajaran berbasis masalah terbukti samasama dapat meningkatkan hasil belajar peserta didik dalam pembentukan kompetensi ekologis melalui keaktifan dan keterlibatan peserta didik dalam proses pembelajaran.

\section{Daftar pustaka}

Aquilina, J. (2001). Environmental education policy for schools: NSW Department of Education and Training Curriculum Support Directorate. New South NSW England: Minister for Education New South NSW.

Cogan, J. J. (1998). Citizenship Education for the 21st Century: setting the context. In J. J. Cogan \& R. Derricott (Eds.), Citizenship for the 21 st Century: An Introduction Perspectives on Education (pp. 1-20).

Echavarria, M. V. (2010). Problem-Based Learning application in engineering. Revista EIA, 14(1), 85-95.

Gunawati, D. (2012). Meranap pembelajaran pendidikan lingkungan hidup dalam konfigurasi pendidikan kewarganegaraan. PKn Progresif, 7(2).

Hosnan, M. (2014). Pendekatan saintifik dan kontekstual dalam pembelajaran abad 21: kunci sukses implementasi kurikulum 2013. Bogor: Ghalia Indonesia.

Husna, S., Nurmaliah, C., \& Abdullah, A. (2013). Penerapan model problem based learning pada konsep perusakan dan pencemaran lingkungan untuk meningkatkan sikap peduli lingkungan siswa SMA Negeri 1 Sabang. Jurnal Edubio Tropika, 1(2), 61-120.
Jeynes, W. H. (2010). Religiosity, religious schools, and their relationship with the achievement gap: a research synthesis and meta-analysis. The Journal of Negro Education, 263-279.

Johnson, E. B. (2011). CTL Contextual Teaching Learning: menjadikan kegiatan belajar mengajar mengasikkan dan bermakna. (I. Setiawan, Trans.). Bandung: Kaifa.

McBride, B. B., Brewer, C. A., Berkowitz, A. R., \& Borrie, W. T. (2013). Environmental literacy, ecological literacy, ecoliteracy: what do we mean and how did we get here? Ecosphere, 4(5), 1-20.

Murdiono, M. (2012). Strategi pembelajaran kewarganegaraan berbasis portofolio. Yogyakarta: Ombak.

Puspandari, D. (2008). Upaya meningkatkan kesadaran pelestarian lingkungan hidup melalui pembelajaran PKLH berbasis CTL. Jurnal Pendidikan Inovatif, 4(1), 28-30.

Schettino, C. (2016). A Framework for Problem-Based Learning: teaching Mathematics with a Relational ProblemBased Pedagogy. Interdisciplinary Journal of Problem-Based Learning, 10(2), 42-67. https://doi.org/10.7771/1541-5015.1602

Sumarmi. (2008). Sekolah hijau sebagai alternatif pendidikan lingkungan hidup dengan menggunakan pendekatan kontekstual. Jurnal Ilmu Pendidikan, 15(1), 19-25.

Suryawati, E., Osman, K., \& Meerah, T. S. M. (2010). The effectiveness of RANGKA contextual teaching and learning on student's problem solving skills and scientific attitude. Procedia - Social and Behavioral Sciences, 9, 1717-1721. https://doi.org/10.1016/j.sbspro.2010.12 .389

Uden, L., \& Beaumont, C. (2006). Technology and problem-based learning. Hershey, London, Melbourne, 
Singapore: IGI Global.

Wahab, A. A., \& Sapriya. (2011). Teori dan landasan Pendidikan Kewarganegaraan. Bandung: Alfabeta.

Yuniwati, \& Siasah, M. (2016). Peningkatan kualitas pembelajaran PPKn melalui penerapan Problem Based Learning di SMP. Harmoni Sosial: Jurnal Pendidikan IPS, 3(2), 199-210. 